\title{
Seasonal Changes in the Fatty Acid Composition of Ewe-Milk Fat
}

\author{
By T. GERSON, F. B. SHORLAND \\ Fats Research Laboratory, Department of Scientific and Industrial Research, Wellington, New Zealand \\ AND C. R. BARNICOAT \\ Massey Agricultural College (University of New Zealand), Palmerston North
}

(Received 15 July 1957)

\begin{abstract}
Although it has long been known that there are seasonal variations in the chemical characteristics of butterfat, it has as yet not been possible to assess the relative importance of nutritional and lactational influences. Moreover, in the Northern Hemisphere the problem is further complicated by the climatic effects, which necessitate the maintenance of cows indoors during the colder months, thereby causing marked changes in the composition and properties of milk fats.
\end{abstract}

It has been shown that the composition of New Zealand butterfat does not vary greatly with locality, but undergoes regular seasonal changes (Cox \& McDowall, 1948; Hansen \& Shorland, 1952).

In a series of papers on the factors causing variations in the yield and composition of the milk of New Zealand Romney ewes grazing under conditions comparable with those of dairy cows (Barnicoat, Logan \& Grant, 1949 $a, b$; Barnicoat, Murray, Roberts \& Wilson, 1956) it has been shown that the lactation curves for yield and composition of ewe's milk are similar to those of the dairy cows, when allowance is made for the different lengths of lactation, which are approximately 12 and 20 weeks respectively.

Ewe's milk yields attained a peak at about 3 weeks, cow's at about 8 weeks, and the fat, protein and solids-not-fat contents of milks of both species, after slight initial declines, showed gradual rises which inclined steeply towards the end of the lactation periods. The lactation curve for the ewe is therefore of similar form to that of the dairy cow, but of only about one-third the duration.

The circumstance that sheep and cattle are both pasture-fed throughout the year in New Zealand has permitted us to compare the chemical com. positions of their milk fats at similar dates and at equivalent stages of lactation, and to produce evidence in support of a theory that the diet is the most important factor responsible for seasonal changes in the composition of their milk fats.

\section{EXPERIMENTAL}

In this work 18 animals were taken at random from a flock of 100 4-year-old Romney ewes at Massey Agricultural College, where they were grazed on improved pasture consisting predominantly of ryegrass and white clover and carrying five to seven ewes/acre. Milk samples were collected over a period of 2-3 days at 5 a.m., after overnight fasting, and coincided with the peak, decline and end of lactation respectively (see Table 1). The fat was obtained from the milk by churning, melting and filtering through paper at $40^{\circ}$.

The ester-fractionation analyses were carried out as outlined by Hansen \& Shorland (1952), with the exception of the steam-volatile distillates. These were neutralized to phenolphthalein with $\mathrm{N}-\mathrm{KOH}$ and a $2 \%$ excess was added. The soap solution was evaporated to dryness and the composition of the fatty acids determined by the procedure of James \& Martin (1952) with gas-liquid chromatography. As shown in Table 2, gas-liquid chromatography was found to give results similar to those obtained by fractional distillation as described by Hansen \& Shorland (1952).

The non-steam-volatile acids were crystallized three times from 10 vol. of acetone at $-40^{\circ}$ and the solid and liquid acids were converted into methyl esters. The distillation was carried out in a helically packed fractionating column (column E, Shorland, 1952), about $40 \mathrm{~g}$. of methyl esters being used. The fatty acid compositions were calculated by the method described by Hilditch (1956). In addition, the proportions of anteiso acids were determined by measuring the optical activity of the fractions, the values obtained by Milburn \& Truter (1954) for the pure compounds being used as standards. The anteiso acids were allowed for in calculating the fatty acid compositions. isoand $n$-Odd-numbered acids have been found in cow-milk

Table 1. Characteristics of samples of ewe-milk fat

\begin{tabular}{|c|c|c|c|c|c|c|c|}
\hline $\begin{array}{c}\text { Sample } \\
\text { no. }\end{array}$ & $\begin{array}{c}\text { Stage of } \\
\text { lactation } \\
\text { (weeks) }\end{array}$ & $\begin{array}{c}\text { Average } \\
\text { milk yield } \\
\text { (kg./day) }\end{array}$ & $\begin{array}{l}\text { Average } \\
\text { fat yield } \\
\text { (g./day) }\end{array}$ & $\begin{array}{c}\text { Fat in } \\
\text { milk } \\
(\%)\end{array}$ & $\begin{array}{c}\text { Acid } \\
\text { value }\end{array}$ & $\begin{array}{l}\text { Iodine } \\
\text { value } \\
\text { (Wijs) }\end{array}$ & $\begin{array}{c}\text { Saponification } \\
\text { equivalent }\end{array}$ \\
\hline $\begin{array}{l}\mathbf{1} \\
\mathbf{2} \\
\mathbf{3}\end{array}$ & $\begin{array}{c}4 \text { (peak) } \\
8 \frac{1}{2} \text { (decline) } \\
14 \frac{1}{2} \text { (end) }\end{array}$ & $\begin{array}{l}1 \cdot 78 \\
1 \cdot 42 \\
0 \cdot 93\end{array}$ & $\begin{array}{l}79 \cdot 2 \\
76 \cdot 4 \\
59 \cdot 4\end{array}$ & $\begin{array}{l}4 \cdot 44 \\
5 \cdot 38 \\
6 \cdot 39\end{array}$ & $\begin{array}{l}4 \cdot 3 \\
7 \cdot 8 \\
6 \cdot 0\end{array}$ & $\begin{array}{l}45 \cdot 1 \\
45 \cdot 0 \\
41 \cdot 2\end{array}$ & $\begin{array}{l}239 \cdot 9 \\
238 \cdot 1 \\
241 \cdot 8\end{array}$ \\
\hline
\end{tabular}


fat in small amounts (Shorland, 1956) but, as there is no satisfactory analytical technique for determining the percentages present, they have not been recorded in the present work.

The trans-unsaturated acids were determined, as described by Hartman, Shorland \& McDonald (1955), and the di- and poly-enoic acids by the method of Brice, Swain, Herb, Nichols \& Riemenschneider (1952). The results, given in Table 3, are compared with published analyses of butterfat.

\section{DISCUSSION}

As shown in Table 2, the New Zealand and English (Hilditch \& Jasperson, 1944) ewe-milk fats are similar in fatty acid composition, differing mainly in the higher contents of unsaturated $\mathrm{C}_{18}$ acids and lower contents of myristic and palmitic acids in the New Zealand samples. Similar results were obtained by Dhingra (1934) for Indian ewe-milk fat,

Table 2. Comparison of the composition of ewe-milk fat and cow-butterfat fatty acids (moles \%)

Results shown in parentheses were obtained by fractional distillation as described by Hansen \& Shorland (1952). -, Not determined.

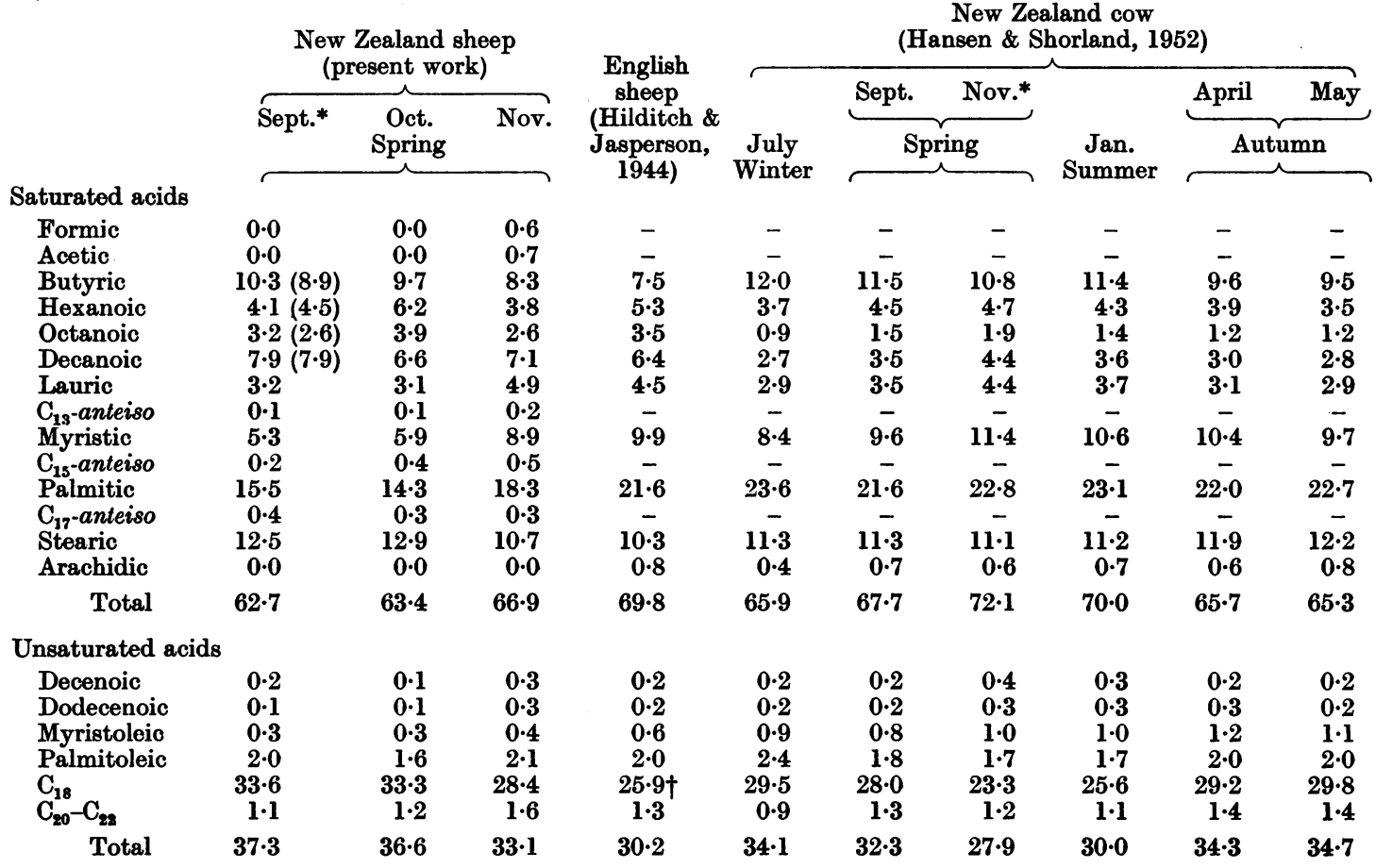

* Peak of production.

$\uparrow 4.3 \%$ linoleic acid has been reported by Hilditch \& Jasperson (1944). This result was presumably based on the iodine values, but later work has shown that other poly- and di-enoic acids are present.

Table 3. Di- and poly-enoic and trans-unsaturated acids of ewe-milk fat and of butterfat

Results are given as \% of total fatty acids.

\begin{tabular}{|c|c|c|c|c|c|}
\hline \multirow{2}{*}{$\begin{array}{c}\text { Sample } \\
\text { no. }\end{array}$} & \multirow{2}{*}{$\begin{array}{l}\text { Conjugated* } \\
\text { diene acids }\end{array}$} & \multicolumn{3}{|c|}{ Unconjugated acids } & \multirow{2}{*}{$\begin{array}{l}\text { trans- } \\
\text { Unsaturated } \\
\text { acids }\end{array}$} \\
\hline & & Diene & Triene & Tetraene & \\
\hline \multicolumn{6}{|c|}{$\begin{array}{l}\text { Ewe-milk fat } \\
\text { (present work) }\end{array}$} \\
\hline $\begin{array}{l}1 \\
2 \\
3\end{array}$ & $\begin{array}{l}2 \cdot 6 \\
2 \cdot 9 \\
2 \cdot 6\end{array}$ & $\begin{array}{l}1 \cdot 1 \\
1.0 \\
1 \cdot 3\end{array}$ & $\begin{array}{l}1 \cdot 4 \\
1 \cdot 4 \\
1 \cdot 3\end{array}$ & $\begin{array}{l}0 \cdot 3 \\
0 \cdot 3 \\
0 \cdot 4\end{array}$ & $\begin{array}{l}11.9 \\
13.5 \\
11.0\end{array}$ \\
\hline Butterfat $\dagger$ & $0 \cdot 7-1 \cdot 4$ & $0.2-0.9$ & $0.5-1 \cdot 0$ & $0.3-1.4$ & $5 \cdot 0-9 \cdot 7 \ddagger$ \\
\hline
\end{tabular}

* Conjugated triene and tetraene acids not found.

‡ Cornwell, Backderf, Wilson \& Brown (1953).

$\uparrow$ McDowell (1953). 
but no values for the lower unsaturated fatty acids were recorded. Neither Hilditch \& Jasperson (1944) nor Dhingra (1934), however, gave details concerning the breed, diet or stage of lactation.

It will be observed in Table 2 that the contents of octanoic and decanoic acids and $\mathrm{C}_{18}$ unsaturated acids are higher in New Zealand sheep-milk fat than in New Zealand butterfat, mainly at the expense of palmitic acid. This ranges from $14 \cdot 3$ to $18.3 \%$ in New Zealand ewe-milk fat, as compared with $21 \cdot 6-23 \cdot 6 \%$ in New Zealand butterfat.

In butterfat the most marked change in the composition occurs in November, coinciding with the maximum rate of growth of pasture. At this stage there is a pronounced reduction in the content of $\mathrm{C}_{18}$ unsaturated fatty acids. Ewe-milk fat shows a similar change in composition at this time of the year. In butterfat the decrease in unsaturated $C_{18}$ acids is compensated for by the presence of increased amounts of $\mathrm{C}_{8}-\mathrm{C}_{14}$ saturated acids. In ewe-milk fat the proportions of $\mathrm{C}_{12}-\mathrm{C}_{16}$ saturated acids are increased.

As already mentioned, the period of lactation of the ewe is much shorter than that of the cow. If the stage of lactation were the main factor influencing fatty acid composition, the changes in fatty acid composition would follow the same course in the two animals at corresponding stages. The data in Table 2 lend no support to this view. The results, however, are in accord with the view that food intake is of primary importance in determining the fatty acid composition of these milk fats. Similar conclusions were reached by Hansen \& Shorland (1952) from their studies on seasonal variations of New Zealand butterfat.

Popják, French \& Folley $(1950,1951)$ demonstrated the central role of acetate in milk-fat formation (up to and including palmitic acid). The utilization of acetate for fat formation provides a mechanism for the variation in fatty acid composition.

It is to be expected that in November, when the food intake is high, there will be more acetate available for fat synthesis. However, at this time lactation nears completion in the ewe and the yield of milk declines without a corresponding reduction in fat yield (Table 1 ). This suggests that extra acetate from the increased food supply is involved, resulting in an increase in the total percentage of the saturated fatty acids up to $\mathrm{C}_{16}$ $\mathbf{4 9 . 5} \%$ in September, $\mathbf{4 9 . 7 \%}$ in October and $53.9 \%$ in November) and a reduction in the percentage of $\mathrm{C}_{18}$ unsaturated acids. The decrease in the content of lower volatile fatty acids, however, appears anomalous. A possible explanation may be that separate enzymes are involved in the activation of fatty acids of different chain length (cf. Lynen, 1954).
Analysis of the di- and poly-enoic acids showed no changes during lactation, nor were any significant changes observed in theamounts of trans-unsaturated acids present. From Tables 2 and 3 it will be seen that the amounts of unsaturated fatty acids are higher in ewe-milk fat than in butterfat, as are the contents of conjugated dienoic and non-conjugated di- and tri-enoic acids. The trans-unsaturated acid contents are higher than those observed by Cornwell, Backderf, Wilson \& Brown 1953), who found 5-10 moles $\%$ in butterfat prepared in Ohio, U.S.A.

\section{SUMMARY}

1. The fatty acid composition of Romney ewemilk fat taken at the peak, decline and end of lactation has been determined.

2. It is shown that the reduction in the content of $\mathrm{C}_{18}$ unsaturated acids at the end of November (late spring) is similar to that of cow-milk fats. This period represents the end of lactation for the early-lambing ewe, but only the middle of lactation for the cow.

3. It is suggested that the change in fatty acid composition is associated with the increased food intake in November, and is not greatly influenced by the stage of lactation.

The authors are indebted to Dr J. C. Hawke of the Fats Research Laboratory for gas-liquid chromatographic analyses.

\section{REFERENCES}

Barnicoat, C. R., Logan, A. G. \& Grant, A. I. (1949a). J. agric. Sci. 39, 44.

Barnicoat, C. R., Logan, A. G. \& Grant, A. I. (1949b). J. agric. Sci. 39, 238.

Barnicoat, C. R., Murray, P. F., Roberts, E. M. \& Wilson, G. S. (1956). J. agric. Sci. 48, 9.

Brice, B. A., Swain, M. L., Herb, S. F., Nichols, P. L. \& Riemenschneider, R. A. (1952). J. Amer. Oil Chem. Soc. 29, 279 .

Cornwell, D. G., Backderf, R., Wilson, C. L. \& Brown, J. B. (1953). Arch. Biochem. Biophys. 46, 364.

Cox, G. A. \& McDowall, F. H. (1948). J. Dairy Res. 15, 377. Dhingra, D. R. (1934). Biochem. J. 28, 73.

Hansen, R. P. \& Shorland, F. B. (1952). Biochem. J.52, 207. Hartman, L., Shorland, F. B. \& McDonald, I. R. C. (1955). Biochem. J. 61, 603.

Hilditch, T. P. (1956). The Chemical Constitution of Natural Fats, 3rd rev. ed., p. 588. London: Chapman and Hall. Hilditch, T. P. \& Jasperson, H. (1944). Biochem. J. 38, 443. James, A. T. \& Martin, A. J. P. (1952). Biochem. J. 50, 679. Lynen, F. (1954). Nature, Lond., 174, 962.

McDowell, A. K. R. (1953). J. Dairy Res. 20, 101.

Milburn, A. H. \& Truter, E. V. (1954). J.chem. Soc. p. 3344. Popják, T., French, T. H. \& Folley, S. J. (1950). Biochem.J. 46, xxviii.

Popják, T., French, T. H. \& Folley, S.J. (1951). Biochem. J. 48, 411.

Shorland, F. B. (1952). J. appl. Chem. 2, 438.

Shorland, F. B. (1956). Annu. Rev. Biochem. 25, 101. 